\title{
Reptiles of Satawan Atoll and the Mortlock Islands, Chuuk State, Federated States of Micronesia ${ }^{1}$
}

\author{
Donald W. Buden ${ }^{2}$
}

\begin{abstract}
Twenty species of reptiles are recorded from the Mortlock Islands, Chuuk, Federated States of Micronesia. The eight geckos and eight skinks together comprise $80 \%$ of the herpetofauna; amphibians are absent. Most of the species are widespread in the west-central Pacific, but the recently described gecko Lepidodactylus oligoporus is known only from the type locality on Namoluk Atoll. Hemidactylus frenatus appears to be displacing Gehyra mutilata, which is common only on Namoluk Atoll, where $H$. frenatus is unrecorded. Five species of skinks of the genus Emoia are sympatric on Satawan Atoll. Partial habitat segregation was observed in three morphologically very similar species of Emoia, with $E$. cyanura being more frequently encountered in beach strand and other open, sun-exposed areas; E. caeruleocauda in shady forest; and E. impar in sundappled forest patches.
\end{abstract}

The Mortlock Islands of Chuuk (formerly Truk), Federated States of Micronesia, are among the many small islands of the western Pacific that are poorly known biologically. The reptiles of the Mortlocks have never been surveyed systematically, and herpetological records are scanty. Schmeltz and Krause (1881) recorded Lamprolepis smaragdina (as Lygosoma smaragdina) and Eumeces rufescens (= Eugongylus albofasciolatus?) from the southern Mortlocks (probably Satawan Atoll) and remarked on two species of sea turtles (almost certainly Chelonia mydas and Eretmochelys imbricata) that nested on Uojta (= Weito) Island, Satawan Atoll. Their report is based on notes provided by Johann Kubary, a naturalist and ethnographer employed by the Godeffroy Museum in Hamburg, Germany, who resided in the southern Mortlocks (probably mainly on Ta Island, Satawan Atoll) from March to the end of May 1877. The use of sea turtles as food by the

${ }^{1}$ Manuscript accepted 14 August 2006.

2 Division of Natural Sciences and Mathematics, College of Micronesia-FSM, P.O. Box 159, Kolonia, Pohnpei, Federated States of Micronesia 96941 (e-mail: don_buden@comfsm.fm).

Pacific Science (2007), vol. 61, no. 3:415-428

(C) 2007 by University of Hawai'i Press

All rights reserved
Mortlockese was mentioned briefly in several anthropological studies from the mid- to late 1900s (Tolerton and Rauch 1949?, Nason 1970, Marshall 1972, Borthwick 1977). In addition, Marshall (1975) recorded four species of geckos (and one unidentified as to species) and five skinks from Namoluk Atoll based on collections he made during June and July 1971. There were no other herpetological reports on the Mortlock Islands until the study reported here, which began as part of a biological survey of terrestrial vertebrates and selected insect groups by me on Satawan Atoll in the southern Mortlocks, initially in December 2002 and with follow-up visits in summer 2003 and spring and summer 2004. All six major island groups composing the Mortlocks were visited during summer 2004, chiefly to expand the survey of reptiles and to assess status of fruit bat populations.

\section{Study Area}

The Mortlock Islands of this study are a part of Chuuk, one of the four states (along with Yap, Pohnpei, and Kosrae) composing the Federated States of Micronesia (FSM). The name Mortlock Islands applies also, and somewhat confusingly, to a small group of islands northeast of Bougainville in Papua New Guinea. The FSM, along with the Republic of Belau (= Palau) to the west, make up the 

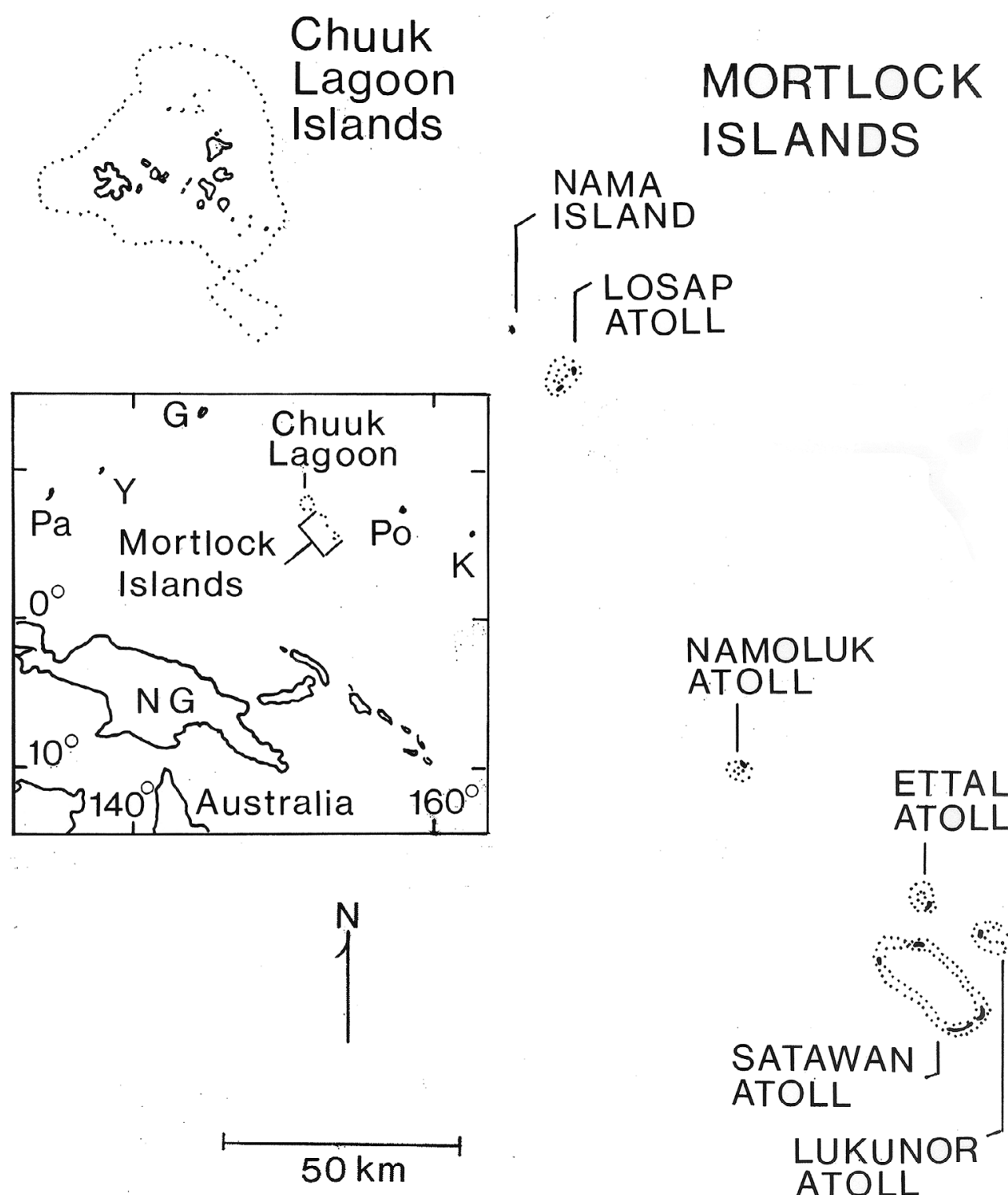

\section{MORTLOCK ISLANDS}

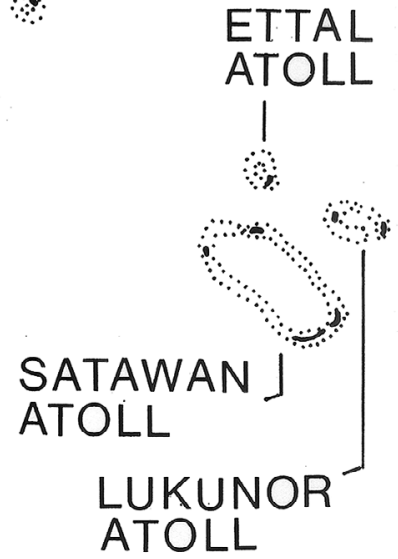

FIgURE 1. Location map for Chuuk Lagoon and the Mortlock Islands, Federated States of Micronesia, and surrounding Pacific islands (inset): G, Guam; K, Kosrae; NG, New Guinea; Pa, Palau; Po, Pohnpei; Y, Yap.

Caroline Islands, which span approximately $3,200 \mathrm{~km}$ of the west-central Pacific Ocean (Figure 1). The Mortlocks are a chain of five atolls and one low coral island that stretches approximately $220 \mathrm{~km}$ southeastward from Nama Island, just south of Chuuk Lagoon, to Satawan Atoll (Figure 2).
The total land area of the Mortlocks is approximately $12 \mathrm{~km}^{2}$ distributed among more than 100 islands (Table 1). The maximum elevations are only 3-5 $\mathrm{m}$ above sea level (asl). The Mortlocks fall within the equatorial rain belt and are wet enough to support a mesophytic vegetation (Mueller-Dombois and 


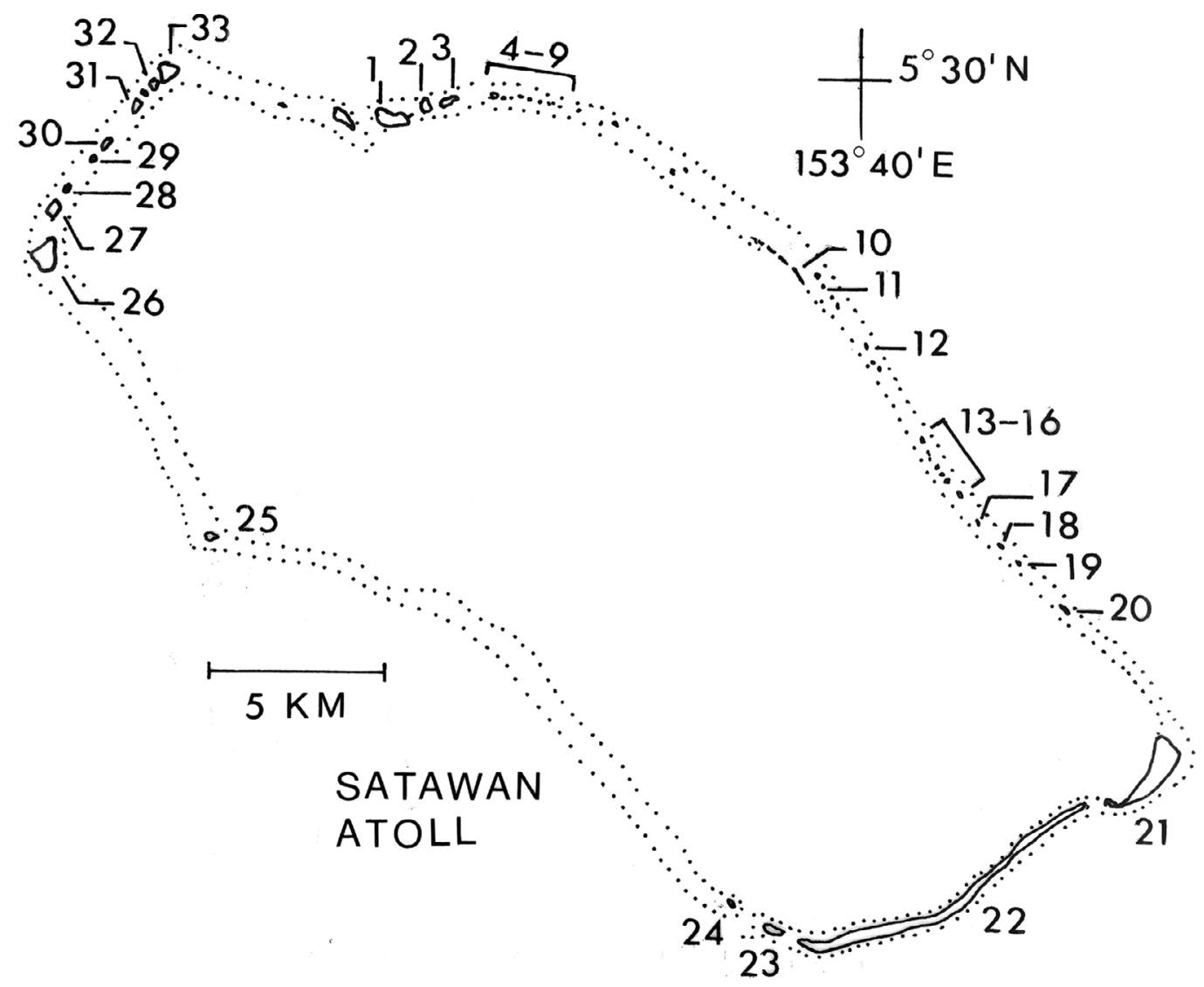

FIGURE 2. Location map for 33 islands of Satawan Atoll included in diurnal surveys of lizards during this study; names of islands are in Table 4.

TABLE 1

Statistical Data for Mortlock Islands, Chuuk, Federated States of Micronesia

\begin{tabular}{lccccc}
\hline \hline Island Group & Land Area $\left(\mathrm{km}^{2}\right)^{a}$ & No. of Islands & Largest Island $\left(\mathrm{km}^{2}\right)^{a}$ & Inhabited Islands & No. of Residents \\
\hline Nama Island & 0.748 & 1 & 0.748 Nama & 1 & 995 \\
Losap Atoll & 1.025 & 10 & 0.562 Lewel & 2 & 875 \\
Namoluk Atoll & 0.834 & 5 & 0.310 Namoluk & 1 & 407 \\
Ettal Atoll & 1.893 & $20^{c}$ & 0.971 Ettal & 1 & 267 \\
Lukunor Atoll & 2.822 & 18 & 1.284 Likinioch & 2 & 1,432 \\
Satawan Atoll & 4.589 & $65^{e}$ & $1.553 \mathrm{Ta}$ & 4 & 2,935
\end{tabular}

\footnotetext{
a Bryan (1971).

${ }^{b}$ Based on the 2000 national census (Division of Statistics 2002).

${ }^{c}$ Based on my count while walking along the outer edge of the reef flat, but Bryan (1971) recorded 18.

${ }^{d}$ Formerly Lukunor Island.

${ }^{e}$ Based on information given to me by Satawan Atoll residents, but the exact number is uncertain. Bryan (1971, unpaged) referred to "approximately" 49 islands in the summary section for "Truk District," but he included at least 80 named and unnamed islands in his Satawan Atoll list of islands and mentioned one area in the northeast section as having "numerous small cays on edge of reef," without naming or numbering them.
} 
Fosberg 1998), though many of the smaller islets lack a freshwater lens and are more xeric. Coconut (Cocos nucifera) forest is the predominant vegetation type, and breadfruit (Artocarpus spp.) is a codominant tree in the interior of the larger islands. Other large, common forest trees include Barringtonia asiatica, Ficus spp., Guettarda speciosa, Hernandia sonora, Neisosperma oppositifolia, Pandanus spp., and Terminalia samoensis. The forest abuts the beach or merges abruptly with a narrow zone of coastal scrub or thicket dominated by Tournefortia argentea and Scaevola taccada. Mangroves are scarce throughout. Some natural depressions and pits excavated for taro cultivation hold water semipermanently, but there is no permanent, standing freshwater. All six major island groups composing the Mortlocks are inhabited, but only one to four islands in each group have permanent settlements. The other (uninhabited) islands are visited with various degrees of frequency to cultivate taro or to harvest natural island commodities such as coconuts, coconut and pandanus leaves, crabs, and firewood.

\section{MATERIALS AND METHODS}

Fieldwork was conducted on Satawan Atoll during 17-26 December 2002, 7 July-1 August 2003, 30 March-9 April 2004, 22 June6 July 2004, and 1-5 August 2004. The five other groups of islands were visited during summer 2004: Nama Island, 2-14 July; Losap Atoll, 10 July; Namoluk Atoll, 19-29 July; Ettal Atoll, 30 July-1 August; and Lukunor Atoll (Likinioch Island only), 2 and 3 August. Transportation to the Mortlocks was by small plane from Pohnpei and Chuuk to Ta Island, Satawan Atoll, which is the location of the only airstrip in the islands. The other major island groups were reached by small boats with outboard motors or by one of the several larger trading boats that service the islands irregularly from Weno (= Moen) in Chuuk Lagoon. Within a single atoll, islands were visited by small boat or, more frequently, by wading across the reef flats at low tide and establishing campsites at the more distant locations. Place names are those used by local residents and closely follow
Bryan (1971); alternative names and variations in spelling abound in the literature.

Of the 656 lizards collected, 648 were fixed in $10 \%$ formalin and transferred to $35 \%$ isopropanol; one Lepidodactylus sp. (and tissue samples from seven others) was preserved in ethanol. Specimens currently are in the College of Micronesia collections. Carapace length of turtles was measured as the straight-line distance from the midpoint of the nuchal notch to the posteriormost edge of the shell, and carapace width as the straight-line distance across the widest part of the shell. A Spearman rank order correlation coefficient for comparing island size against number of species was calculated using VassarStats: Web site for Statistical Computation.

\section{RESULTS}

\section{Turtles}

Chelonia mydas (Linnaeus) and Eretmochelys imbricata (Linnaeus). The green turtle (Chelonia mydas) and the hawksbill turtle (Eretmochelys imbricata) are the only turtles recorded in the Mortlock Islands. Marshall (1975:7) stated that on Namoluk Atoll both species "frequent the lagoon and surrounding waters, with the green turtle being far more common ... [and] now and again they come ashore to lay their eggs on the seaward side of Amwes [= Amas] Islet." He (Marshall 1975:7) went on to say that "turtles of any size are killed whenever possible for their highly prized meat and for their shells which are a valuable item of trade." Marion Henry (in Pritchard 1977:51) reported "casual hawksbill nesting" in the three southernmost atolls (Ettal, Lukunor, and Satawan), "but not commonly on the inhabited islands." Tolerton and Rauch (1949?) remarked briefly on the spearing of "turtles" on Lukunor Atoll, and Borthwick (1977:26) reported that both the green and the hawksbill turtle are found in and around the Lukunor lagoon "but they are not a frequent source of food." Nason (1975:144), reporting on fish and shellfish in the diet of Ettal Atoll residents, stated that "green sea turtles, the only other marine re- 
source utilized, are captured in the lagoon or on one of the islet lagoon beaches three or four times a year."

I saw no hawksbills in the Mortlocks, and the few green turtles I saw were captive or dead. On Satawan Island, Satawan Atoll, I saw one female (carapace length $44.5 \mathrm{~cm}$, width $36 \mathrm{~cm}$ ) in an advanced state of decomposition on the beach on 20 December 2002 (cause of death undetermined) and two others that were freshly killed and being prepared for cooking on 23 July 2003, one measuring 45.5 by $39.0 \mathrm{~cm}$ and the other 51.0 by 45.5 $\mathrm{cm}$. I saw two young (estimated carapace length $15.0 \mathrm{~cm}$ ) in captivity on Moch Island, Satawan Atoll, during mid-July 2003 and was told that members of a resident family of islanders frequently raise young turtles, eventually releasing them into the lagoon. On Nama Island, in July 2004, I was shown an excavated nest of a green turtle from which the eggs had been harvested during the first week of June, and I was informed by local residents that both green and hawksbills are occasionally seen on Nama and at nearby Losap Atoll.

\section{Lizards}

Geckos:

Gehyra mutilata (Wiegman). The stumptoed or mutilating gecko is common on $\mathrm{Na}$ moluk Atoll, scarce to uncommon on Satawan and Kuttu Islands (Satawan Atoll), and unrecorded elsewhere in the Mortlocks; the 11 specimens were collected on the walls of buildings at night.

Gehyra oceanica (Lesson). The oceanic gecko is widespread and common throughout the Mortlocks. It occurs in edificarian habitats commensal with humans as well as in forests and coastal thickets in the more remote and uninhabited areas. It was most frequently encountered on the trunks of coconut trees at night. Marshall (1975:6) did not record G. oceanica on Namoluk Atoll, but his mention of a large gecko that "lives in the crown of coconut palms and has been observed eating smaller geckos" may pertain to this species. However, his estimate of body size ("approximately 300 millimeters" [Marshall 1975:6]) is much larger than this species attains.
Hemidactylus frenatus Dumeril \& Bibron. The house gecko is a relatively recent (postWorld War II) introduction to many Pacific islands (Hunsaker 1966, Case et al. 1994), including the eastern Carolines (Buden 2000). It is locally common in the Mortlock Islands and recorded here for the first time on five of the six main island groups. Its absence from only Namoluk Atoll may be real because it was not recorded by Marshall (1975), who resided on Namoluk for 15 months during 1968-1971, nor by me during 19-27 July 2004. I recorded $H$. frenatus elsewhere in the Mortlocks only in the settlements and only in edificarian habitats, where it was often the most abundant gecko. Five or six would often be within a $1-\mathrm{m}$ radius of an incandescent lamp, feeding on insects drawn to the light. The maximum encounter rate was 27 in 15 $\min (108 / \mathrm{hr})$ at Ta Island elementary school, 24 December 2002.

Lepidodactylus oligoporus Buden. This newly described species is known only from the holotype and four paratypes, all collected in Scaevola shrubs on Toimon Island, Namoluk Atoll, Mortlock Islands, at night on 20 July 2004 (Buden 2007). I suggest the common name Mortlock Islands scaly-toed gecko for this species.

Lepidodactylus lugubris complex. The $75 \mathrm{ex}-$ amples of geckos in the L. lugubris complex collected from throughout the Mortlock Islands during this study include 18 males (based on external morphology and/or everted hemipenes) and 57 females. They exhibit a bewildering array of variation in coloration and pattern and appear to include examples of L. moestus (Peters), different clones of the unisexual species L. lugubris (Dumeril \& Bibron), and hybrids. An assessment of their distribution and habitat preferences in the Mortlocks requires further study.

Nactus pelagicus (Girard). The slender-toed or rock gecko is uncommon to locally common throughout the Mortlocks. It is usually seen at night, perched low on tree trunks in rocky areas or foraging in coral rubble in the upper beach zone. Unlike the other gecko species in Micronesia, which attempt to escape capture by ascending the trunk, $N$. pelagicus usually evades pursuit by descending and 
taking shelter in the interstices of the surrounding rocks or in the holes and crevices at the base of the trunk. It is occasionally encountered on cement and stone walls and linings of wells and cisterns. The maximum encounter rates were 8 in $50 \mathrm{~min}(10 / \mathrm{hr})$ on tree trunks and 5 in $50 \mathrm{~min}(6 / \mathrm{hr})$ in coral rubble on Kuttu Island, Satawan Atoll, on 6 April and 30 March 2004, respectively.

Perochirus ateles (Dumeril). The Micronesian gecko is one of the most widespread and frequently encountered geckos in the Mortlocks. It was recorded on all the island groups and on 29 of the 35 islands surveyed on Satawan Atoll. The six islands where $P$. ateles was not encountered represent a diversity of habitats wherein it has been recorded elsewhere on the atoll. The lack of records in these cases may be a result of incomplete sampling. Two of the islands (Moch and Kuttu) are relatively large and densely populated, one ( $\mathrm{Ma}-$ sawech) is one of the smallest islets and is uninhabited and covered with xerophytic beach scrub, and the three others (Lemasul, Lelang, and Foui) are small to moderately sized, uninhabited, and forested. Perochirus ateles occurs in edificarian and ruderal habitats as well as in the less-disturbed forest areas in the more remote and uninhabited islands, often syntopically with the similarly sized Gebyra oceanica, although, of the two species, $P$. ateles is more likely to be found in exclusive colonies. The maximum encounter rate was 45 in $15 \mathrm{~min}(180 / \mathrm{hr}$ ) in palm leaf axils (with a maximum of eight in one palm) on Enekap Island, Satawan Atoll, on 28 June 2004. Many individuals collected in the Mortlocks had at least one or two small (1-2 $\mathrm{mm}$ in diameter) orange spots at various locations on the dorsum, a feature not noted in specimens collected from Pohnpei State islands (pers. obs.).

Skinks:

Emoia boettgeri (Sternfeld). The Boettger's skink is uncommon to common throughout the Mortlocks but inexplicably absent or scarce from some of the islands with seemingly suitable habitat. This species is most numerous in shady forest habitats with sparse ground cover, including sites where pigs have been rooting, and it is usually seen on the ground or low on tree trunks. It is also com- mon along forest edges adjacent to rocky beaches. It was the only species of Emoia found on tiny ( $0.17 \mathrm{ha}$ ) Aliare Island (Satawan Atoll), which was the only island in the Mortlocks where it was the sole member of the genus. The maximum recorded encounter rate was 10 in $13 \mathrm{~min}(46 / \mathrm{hr})$ on Mariong Island, Satawan Atoll, on 11 July 2003.

Emoia caeruleocauda (De Vis). The Pacific blue-tailed skink is common throughout the Mortlocks and was recorded on 17 of the 35 islands surveyed on Satawan Atoll. This species occurs syntopically with E. impar but is more often found in shaded forest than in open sun-exposed areas, where the latter is more abundant. The maximum encounter rate was 49 in $10 \mathrm{~min}(294 / \mathrm{hr})$ on Foui Island, Satawan Atoll, on 20 July 2003, where the only other Emoia species recorded was a single E. cyanura.

Emoia cyanura (Lesson). The brown-tailed copper-striped skink is recorded in the Mortlock Islands only on Satawan Atoll and only on 9 of the 35 islands surveyed, all in the northern part of the atoll-eight of the islands are in the Moch District, between Moch and Faupuker, and the other (Pien) is more to the northwest, in Kuttu District. This species is usually seen in grassy, weedy, sand strand or in broad, open areas in forest. The record from Foui is based on a single specimen that was collected among numerous E. caeruleocauda; no others were seen. On the other hand, E. cyanura was unusually abundant on Fauchan Lengileng Island on 22 July 2003, at which time much of the undergrowth had been cleared; the encounter rate was 52 in $5 \mathrm{~min}(624 / \mathrm{hr})$.

Emoia impar (Werner). The blue-tailed copper-striped skink is one of the most common lizards in the Mortlocks. Its absence from Lukunor Atoll is probably an artifact of sampling. It was recorded on 20 of the 35 islands sampled on Satawan Atoll and more frequently in open, sun-exposed areas than in completely shaded forest. The maximum recorded encounter rate was 55 in $30 \mathrm{~min}$ (110/hr) on Onupuku Island, Satawan Atoll, on 9 July 2003.

Emoia jakati (Kopstein). The Jakati skink is locally common in open, sparsely vegetated 
areas, especially in the vicinity of human habitation and in short grasses, weeds, and vines in coastal strand. It is recorded throughout the Mortlocks though absent from many of the more remote and uninhabited islands. The maximum encounter rate was 26 in 30 min (52/hr) on Moch Island, Satawan Atoll, on 17 July 2003. This species was unrecorded on Namoluk by Marshall (1975), who spent at least 15 months in residence during 19691971, and thus suggests the possibility of a more recent introduction there.

Eugongylus albofasciolatus (Günther). The white-striped cape skink (= reclusive litter skink) is fairly common throughout the Mortlocks. The absence of records from Lukunor Atoll is almost certainly an artifact of sampling. It was most frequently encountered in or very near piles of trash or accumulated plant debris, at the edges of grassy weedy areas, and among the exposed roots of trees. The animals often afforded only brief glimpses before retreating to shelter in underground holes or slithering beneath rocks and logs. Several were observed feeding on coconuts that had been split open and left behind by islanders, probably as bait for coconut crabs (Birgus latro).

Lamprolepis smaragdina (Lesson). The emerald skink is common throughout the Mortlocks (maximum encounter rate $109 / \mathrm{hr}$ - see Nama Island notes later in this paragraph) and usually observed on tree trunks, less frequently on vines and on the ground. Among the 104 on Satawan Atoll for which dorsal coloration was recorded, 97 (93\%) were brown, two were greenish brown, four were "mustard" or yellowish brown, and two were green. Brown individuals predominated in other areas of the Mortlocks as well, including $61(95 \%)$ of 64 recorded during a $35-$ min survey $(109 / \mathrm{hr})$ on Nama Island on 29 July 2004, the 18 observed during a 20-min survey on Namoluk Island, Namoluk Atoll, on 29 July 2004, three of the four collected on Losap Atoll, and the one each from Ettal and Lukunor Atolls during July and August 2004.

Lipinia noctua (Lesson). The moth skink is known in the Mortlocks from Namoluk, Ettal, and Satawan Atolls. It is probably more widespread and more numerous than records indicate; its cryptic habits make assessment difficult. It was most frequently encountered in palm leaf axils, in the fibrous matter at the petiole bases of coconut palms, and beneath the flaking bark of dead trees.

\section{Monitor Lizards}

Varanus indicus (Daudin). The water monitor is uncommon to common on at least one to several islands on each of the three southernmost atolls (Ettal, Lukunor, Satawan), but it is unexpectedly absent from immediately adjacent and seemingly very similar islands on these atolls and it is unrecorded in the more northern Mortlocks. Monitors were observed on open sandy beaches, on the forest floor, on tree trunks in coconut forest, and resting at the water's edge in taro pits. Others were heard scrambling through the undergrowth in dense coastal scrub and thickets or running through the water in taro pits. Resident islanders told me that monitors were introduced during the Japanese administration. On Satawan Atoll, I saw monitors frequently on Satawan Island and during brief visits to Lemasul and Alengarik Islands. One resident of Ta told me of seeing monitors there occasionally during the 1970s and 1980s but none recently. Nason (1970:35) reported that "the giant monitor was introduced [to Ettal Atoll] by the Japanese for rat control on Parang [Island]," and that it was still restricted to that island, at least through the 1960s. I saw three $V$. indicus on Parang and one on adjacent Alenganmales Island on 31 July 2004. I saw no $V$. indicus on Likinioch Island, Lukunor Atoll, during my brief visit but was told by local residents that they occur there and on several other islands on the atoll. Borthwick (1977) reported that monitor lizards were introduced to Likinioch by the Japanese.

\section{Snakes}

Pelamis platurus (Linnaeus). The yellowbellied sea snake has been recorded occasionally in the waters of the Caroline Islands (Crombie and Pregill 1999, Buden 2000). 
One "found in a drift log someone had dragged to the interior of [Pis-Losap Island, Losap Atoll] ... March 1972" is the first record for the Mortlock Islands (Craig Severance, e-mail with photo attached, October 2005).

\section{DISCUSSION}

The herpetofauna of the Mortlock Islands consists of at least 20 species of reptiles, including eight geckos, eight skinks, two sea turtles, one monitor lizard, and one sea snake; amphibians are lacking. The marine toad, Bufo marinus, is introduced and widespread on nearby Chuuk and the other high islands of the FSM, including Yap, Pohnpei, and Kosrae (Eldredge 2000, Lever 2001), but there are no confirmed records for the Mortlock Islands. The report of B. marinus as being "established and expanding" in the Mortlock Islands, Micronesia (ISSG Global Invasive Species Database, 2006), with Lever (2001) given as a source, is almost certainly an error in confusing the Mortlock Islands of Micronesia with the Mortlock Islands of Papua New Guinea. The Lever (2001) account has no mention of B. marinus in the Mortlock Islands in the FSM section but does so for Mortlock Islands in Bougainville, a part of Papua New Guinea.

With few exceptions, the reptile species recorded in the Mortlocks are widespread throughout the Carolines and often well beyond. The recently described Lepidodactylus oligoporus, however, is known only from the type locality on Namoluk Atoll and possibly is endemic to the Mortlocks; other species of Lepidodactylus in the Group II complex (sensu Brown and Parker 1977) also are known only from very limited geographic areas (Buden 2007). The monitor lizard Varanus indicus, which has a spotty distribution in Micronesia, is introduced and apparently confined in the Mortlocks to a few islands in the three southernmost atolls, and the sea snake Pelamis platurus is known in the Mortlocks only from a single record from Losap Atoll, but it is a pelagic species widespread throughout the tropical Pacific.

\section{Habitat Preference}

Among Mortlock Islands geckos, both Gehyra mutilata and Hemidactylus frenatus are adventitious species recorded only in edificarian habitats; G. mutilata is largely uncommon, whereas $H$. frenatus is the most abundant species in areas of human habitation, at least on Satawan Atoll (Tables 2 and 3). It is interesting that G. mutilata was most numerous on Namoluk Atoll, the only island group in the Mortlocks where $H$. frenatus is unrecorded. Hemidactylus frenatus may be displacing $G$. mutilata in the Mortlocks as it has displaced several species in competitive situations elsewhere in the Pacific (Petren et al. 1993, Case et al. 1994, McCoid 1996, Crombie and Pregill 1999). The other gecko species are more widely distributed in several different habitats, including coconut forest, the predominant vegetation type. Gebyra oceanica was frequently encountered on tree trunks and usually higher than $1 \mathrm{~m}$ above the ground, whereas Nactus pelagicus was encountered nearer the base of the trunk, usually within 1 $\mathrm{m}$ of the ground. Members of the Lepidodactylus lugubris complex were most frequently encountered at night in Scaevola shrubs along the beach and on the walls of buildings. But details of their distribution in the Mortlocks remain unclear because sight records could not confidently be assigned to species, and much of the collected material is as yet unidentified.

Of the eight species of skinks recorded in the Mortlocks, Lipinia noctua was encountered only in cryptic habitats, including palm leaf axils, the accumulated fibrous debris at the base of coconut palm crowns, and under the loose bark on both standing and fallen tree trunks. Eugongylus albofasciolatus was somewhat less secretive but usually afforded only brief glimpses before disappearing from view. It was most frequently encountered on the ground and mainly during late afternoon and early evening. Of the six diurnally active skinks, Lamprolepis smaragdina was the most arboreal, although it was also often seen on the ground. Conversely, Emoia boettgeri, E. caeruleocauda, and E. impar were usually seen on the ground and on low herbaceous ground 
TABLE 2

Distribution of Reptiles in the Mortlock Islands, with Number of Specimens Collected during 2002-2004 Surveys

\begin{tabular}{|c|c|c|c|c|c|c|}
\hline \multirow[b]{2}{*}{ Species } & \multirow[b]{2}{*}{ Nama I. } & \multicolumn{5}{|c|}{ Atolls ${ }^{a}$} \\
\hline & & Los & $\mathrm{Nam}$ & Ett & Luk & Sat \\
\hline \multicolumn{7}{|l|}{ Turtles } \\
\hline Chelonia mydas & $t^{b}$ & $+^{b}$ & $+^{c}$ & $+^{d}$ & $+^{e}$ & $+^{d, f}$ \\
\hline Eretmochelys imbricata & $+^{b}$ & $t^{b}$ & $+^{c}$ & $+^{g}$ & $+^{e, g}$ & $+^{g}$ \\
\hline \multicolumn{7}{|l|}{ Geckos } \\
\hline Gebyra mutilata & & & 8 & & & 3 \\
\hline G. oceanica & 1 & & 2 & 1 & 1 & 20 \\
\hline Hemidactylus frenatus & 3 & 1 & & 3 & 2 & 14 \\
\hline Lepidodactylus oligoporus & & & 5 & & & \\
\hline L. lugubris complex ${ }^{b}$ & 10 & 1 & 14 & 4 & 3 & 43 \\
\hline Nactus pelagicus & 2 & & 9 & 3 & 1 & 23 \\
\hline Perochirus ateles & 5 & 2 & 1 & 1 & 2 & 71 \\
\hline \multicolumn{7}{|l|}{ Skinks } \\
\hline Emoia boettgeri & 4 & 3 & 2 & 1 & 1 & 27 \\
\hline E. caeruleocauda & 8 & 8 & 5 & 2 & 3 & 105 \\
\hline E. cyanura & & & & & & 45 \\
\hline E. impar & 3 & 3 & 2 & 1 & & 101 \\
\hline E. jakati & 2 & 1 & 1 & 1 & 1 & 18 \\
\hline Eugongylus albofasciolatus & 2 & 1 & 3 & 1 & & 6 \\
\hline Lamprolepis smaragdina & 4 & 4 & 1 & 1 & 1 & 18 \\
\hline Lipinia noctua & & & 1 & 1 & & 6 \\
\hline \multicolumn{7}{|l|}{ Monitor lizards } \\
\hline Varanus indicus & & & & $+f$ & $+^{b}$ & $+^{f}$ \\
\hline \multicolumn{7}{|l|}{ Snakes } \\
\hline Pelamis platurus & & $+^{i}$ & & & & \\
\hline
\end{tabular}

${ }^{a}$ Los, Losap; Nam, Namoluk; Ett, Ettal; Luk, Lukunor; Sat, Satawan.

${ }^{b}$ Based on information provided to me by local residents.

${ }^{c}$ Marshall (1975).

d Nason (1975).

${ }^{e}$ Borthwick (1977).

$f$ Pers. obs.

$g$ Pritchard (1977)

${ }^{b}$ Includes L. lugubris, L. moestus, and hybrids.

${ }^{i}$ Based on a photograph by C. Severance-see species account.

TABLE 3

Observation Rate (Animals per Hour) and Percentage Frequency of Encounters of Geckos in Five Habitats on Satawan Atoll

\begin{tabular}{|c|c|c|c|c|c|}
\hline \multirow[b]{2}{*}{ Species } & \multirow{2}{*}{$\frac{\text { Day }}{\text { Palm Leaf Axils }} \underset{13.1 / 38 \%[23]^{a}}{ }$} & \multicolumn{4}{|c|}{ Night } \\
\hline & & $\begin{array}{l}\text { Tree Trunks } \\
8.3 / 24 \%[12]\end{array}$ & $\begin{array}{c}\text { Scaevola Shrubs } \\
5.5 / 16 \%[13]\end{array}$ & $\begin{array}{c}\text { Coral Rubble } \\
3.1 / 9 \%[6]\end{array}$ & $\begin{array}{c}\text { Edificarian } \\
4.5 / 13 \%[4]\end{array}$ \\
\hline Gebyra mutilata & & & & & $1.1(100 \%)$ \\
\hline Gebyra oceanica & $2.7(40.2 \%)$ & $4.9(47.1 \%)$ & $0.2(1.2 \%)$ & & $2.2(11.5 \%)$ \\
\hline Hemidactylus frenatus & & & & & $45.3(100 \%)$ \\
\hline Lepidodactylus lugubris complex & $1.5(12.0 \%)$ & $0.4(1.8 \%)$ & $15.1(50.0 \%)$ & $2.6(4.8 \%)$ & $11.6(31.3 \%)$ \\
\hline Nactus pelagicus & & $2.8(67.6 \%)$ & & $2.9(26.5 \%)$ & $0.4(5.9 \%)$ \\
\hline Perochirus ateles & $13.8(66.2 \%)$ & $1.8(5.4 \%)$ & $13.6(27.3 \%)$ & & $0.7(1.1 \%)$ \\
\hline
\end{tabular}

${ }^{a}$ Search effort indicated as number of observation hours/percentage of total observation time (34.4 hr), with total number of islands surveyed in brackets. 
cover and less frequently on tree trunks, and E. cyanura was almost entirely terrestrial.

\section{Distribution of Skinks on Satawan Atoll}

Distribution patterns of lizards within the atolls are difficult to assess because of incomplete surveys. However, the 314 specimens of six diurnal species of skinks from among 30 islands of Satawan Atoll allow for at least a preliminary assessment. Five additional islands were surveyed, but no skinks were recorded on them; two (Pielisiop and Tewanikich) were visited briefly and only at night and are excluded from further comparisons, and the three others (Chacha, Masawech, and Letau) are among the smallest of the islands, each less than 0.4 ha (Table 4).

Eugongylus albofasciolatus and Lipinia noctua are cryptic species that probably are more common and widespread than the relatively few records indicate; they are excluded from further comparisons for lack of sufficient data. Five of the other six species belong to the genus Emoia. Four of them are small and overlap broadly in snout-vent length (E. jakati 37-53 mm, E. impar 40-47 mm, E. caeruleocauda $40-65 \mathrm{~mm}$, E. cyanura $40-55 \mathrm{~mm}$ ); one is medium-sized (E. boettgeri $60-77 \mathrm{~mm}$ ); the other species, Lamprolepis smaragdina, is much larger $(>100 \mathrm{~mm})$; measurements are from Kiester (1983), Brown (1991), and Zug (1991).

The larger among the 33 islands surveyed tend to support a larger number of these six species. The Spearman rank order correlation coefficient for island area against the number of species is $0.9268 \quad(n=33, t=13.74$, $\mathrm{df}=31, P<.000001)$. With the exception of Pike (5.18 ha), the 14 islands with only one or two species are less than 2.0 ha (Table 4). However, Lamprolepis smaragdina possibly was overlooked on Pike because it is present on all the other islands surveyed in that part of the atoll, as well as on some much smaller islands elsewhere. The eight islands with three to four species range in size from approximately 2 to slightly more than $6 \mathrm{ha}$, and the seven islands with five species (lacking only E. cyanura) are all greater than 7.0 ha; Moch
(32.58 ha), the fourth largest island, is the only one where all six were recorded.

Where only one of the six species occurs on an island, it is invariably one of the small species-E. impar in four cases, E. cyanura in three, and E. caeruleocauda in one. An array of different combinations of species was found among islands with two to four species. No consistent pattern was evident in these instances although Lamprolepis smaragdina, the largest species, and the most arboreal, was present on all islands with three or more skink species (Table 5).

Three species of Emoia that are very similar in coloration and pattern as well as body size are sympatric (and to various degrees syntopic) in different combinations on Satawan Atoll. Emoia cyanura is the least common, being recorded on only nine of the 33 islands surveyed. It occurred with both E. caeruleocauda and E. impar only on Moch, with just E. caeruleocauda on two other islands, with just E. impar on two others, and without either of the two on four islands (Table 5). It was the only skink on three $(33 \%)$ of the nine islands where it was recorded. Emoia caeruleocauda and E. impar were recorded on 17 and 20 islands, respectively, sympatrically on 12. Resource utilization among these species was not investigated quantitatively, but specimen records together with incidental observations indicate that E. cyanura is more common in beach strand and in broad, sunexposed clearings and disturbed areas, whereas E. caeruleocauda and E. impar are more common in shady forest, with $E$. impar showing a greater predilection for patches of sunlight. All three were found in forest edges along the beach. Similar separation or partial separation in habitat between E. cyanura and E. impar was recorded in Fiji (Zug 1991), the Cook Islands (Bruna et al. 1996a), and American Samoa (Schwaner and Ineich 1998).

Geographic patterns of distribution of skinks on Satawan Atoll probably are due in large part to a concentration of smaller islands along the northeastern and eastern sides of the atoll, where all but one of the 14 islands surveyed between Pis (Moch District) and Letau (Satawan District) are less than 
TABLE 4

Distribution of Six Species of Skinks on 33 Islands of Satawan Atoll Based on Sight Records (SR) and 430 Specimens Collected during 2001-2004

\begin{tabular}{|c|c|c|c|c|c|c|c|c|c|}
\hline \multirow[b]{2}{*}{ Island } & \multirow[b]{2}{*}{ Area (ha) } & \multirow[b]{2}{*}{ Time $^{a}$} & \multirow[b]{2}{*}{ No. of Species } & \multicolumn{5}{|c|}{ Emoia $^{b}$} & \multirow[b]{2}{*}{$\mathrm{Ls}$} \\
\hline & & & & bt & $\mathrm{ca}$ & cy & $\mathrm{im}$ & $\mathrm{ja}$ & \\
\hline 1 Moch & $32.58^{d}$ & $3 \mathrm{~d}$ & 6 & SR & 12 & 3 & 1 & 1 & SR \\
\hline 2 Oninuk & $6.22^{e}$ & $1.5 \mathrm{hr}$ & 3 & 1 & & 5 & & & 1 \\
\hline 3 Lelang & $6.73^{e}$ & $1 \mathrm{hr}$ & 4 & 1 & & 5 & 5 & & SR \\
\hline 4 Fecha & $1.81^{e}$ & $1 \mathrm{hr}$ & 1 & & & & 8 & & \\
\hline 5 Wonalang & $3.14^{f}$ & $3 \mathrm{hr}(2)$ & 3 & & & 4 & 3 & & SR \\
\hline 6 Pis & $0.05^{f}$ & $1 \mathrm{hr}(2)$ & 1 & & & & 2 & & \\
\hline 7 Manimwek & $0.98^{f}$ & $3 \mathrm{~d}$ & 2 & & & & 7 & & SR \\
\hline 8 Foui & $1.80^{f}$ & $1 \mathrm{hr}$ & 2 & & 8 & 1 & & & \\
\hline 9 Pokonopo & $0.16^{f}$ & $1 \mathrm{hr}$ & 1 & & & 2 & & & \\
\hline 10 Chacha & $0.15^{f}$ & $1.5 \mathrm{hr}(2)$ & 0 & & & & & & \\
\hline 11 Fauchan & $0.63^{f}$ & $2 \mathrm{hr}(2)$ & 1 & & & 8 & & & \\
\hline 12 Faupuker & $0.38^{f}$ & $2 \mathrm{~d}$ & 1 & & & 5 & & & \\
\hline 13 Pononkis & $0.87 \mathrm{~g}$ & $2 \mathrm{hr}$ & 1 & & & & 5 & & \\
\hline 14 Pononlap & $1.55^{g}$ & $1 \mathrm{~d}$ & 2 & & 5 & & 4 & & \\
\hline 15 Masawech & $0.32 g$ & $1 \mathrm{hr}(2)$ & 0 & & & & & & \\
\hline 16 Simelap & $0.65^{g}$ & $2 \mathrm{hr}(2)$ & 1 & & & & 5 & & \\
\hline 17 Enekap & $0.59 g$ & $3 \mathrm{hr}$ & 1 & & 7 & & & & \\
\hline 18 Ewal & $0.89 g$ & $2 \mathrm{hr}$ & 2 & & 4 & & 3 & & \\
\hline 19 Letau & $0.11^{g}$ & $3 \mathrm{hr}(2)$ & 0 & & & & & & \\
\hline 20 Fatikat & $1.64 g$ & $3 \mathrm{~d}$ & 3 & 5 & 2 & & & & SR \\
\hline 21 Satawan & $112.15^{e}$ & $7 \mathrm{~d}$ & 5 & 4 & 12 & & 2 & 8 & 3 \\
\hline $22 \mathrm{Ta}$ & $155.40^{e}$ & $19 \mathrm{~d}$ & 5 & 2 & 13 & & 9 & 3 & 6 \\
\hline 23 Weito & $7.77^{e}$ & $3 \mathrm{~d}$ & 5 & 2 & 7 & & 9 & 1 & 2 \\
\hline 24 Aliare & $0.17 \mathrm{~g}$ & $6 \mathrm{hr}(2)$ & 2 & 3 & & & & & 3 \\
\hline 25 Onupuku & $4.66^{e}$ & $10 \mathrm{hr}(2)$ & 3 & 1 & & & 3 & & SR \\
\hline 26 Kuttu & $35.27^{d}$ & $5 \mathrm{~d}$ & 5 & SR & 6 & & 11 & 1 & 2 \\
\hline 27 Orin & $11.40^{e}$ & $6 \mathrm{hr}(2)$ & 5 & 2 & 2 & & 1 & 2 & 1 \\
\hline 28 Pien & $3.89^{e}$ & $4 \mathrm{hr}(2)$ & 3 & & 7 & 12 & & & SR \\
\hline 29 Pike & $5.18^{e}$ & $2 \mathrm{hr}(2)$ & 2 & & 5 & & 9 & & \\
\hline 30 Mariong & $5.96^{e}$ & $4 \mathrm{hr}(2)$ & 4 & 2 & 7 & & 2 & & SR \\
\hline 31 Apisson & $6.45^{d}$ & $1.5 \mathrm{hr}(2)$ & 4 & SR & 3 & & & SR & SR \\
\hline 32 Lemasul & $7.37^{d}$ & $3 \mathrm{~d}$ & 5 & 2 & 1 & & 5 & 1 & SR \\
\hline 33 Alengarik & $17.56^{d}$ & $6 \mathrm{hr}(2)$ & 5 & 2 & 4 & & 7 & 1 & SR \\
\hline
\end{tabular}

a Approximate number of days (d) or hours (hr) on each island, with number of visits (in parentheses) for islands visited for less than a day but on more than one day.

${ }^{b}$ bt, E. boettgeri; ca, E. caeruleocauda; cy, E. cyanura; im, E. impar; ja, E. jakati.

c Lamprolepis smaragdina.

${ }^{d}$ Calculated for me by D. Tabarosi based on a digitized U.S. Army Corps of Engineers topographic map, overlain with recent satellite imagery to confirm accuracy.

e From Bryan (1971).

$f$ Roughly estimated from hip chain measurements of island length and width made by me during this study.

$g$ Calculated with a Garmin Global Positioning System unit after walking the circumference of the island during this study.

1.0 ha in area. Emoia boettgeri and E. jakati are completely absent from these islands, and Lamprolepis smaragdina was recorded only on Manimwek. On the other hand, E. cyanura was encountered more frequently on these northern and northeastern islands, whereas
E. caeruleocauda and E. impar were more spottily distributed. Conversely, with the exception of Pien Island in the northwest, $E$. cyanura was unrecorded elsewhere on the atoll, where E. boettgeri, E. caeruleocauda, and E. impar were more numerous. 
TABLE 5

Distribution of Different Combinations among Six Species of Skinks on Satawan Atoll

\begin{tabular}{|c|c|c|c|c|}
\hline \multirow[b]{2}{*}{ No. of Species on Island } & \multicolumn{2}{|c|}{ Species } & \multicolumn{2}{|c|}{ Island } \\
\hline & Name $^{a}$ & Size Class ${ }^{b}$ & Name & Area (ha) \\
\hline 1 & $\mathrm{ca}$ & $\mathrm{S}$ & Enekap & 0.59 \\
\hline 1 & cy & $\mathrm{S}$ & Fauchan Lengeleng & 0.63 \\
\hline 1 & cy & $\mathrm{S}$ & Faupuker & 0.38 \\
\hline 1 & cy & $\mathrm{S}$ & Pokonopo & 0.16 \\
\hline 1 & im & $\mathrm{S}$ & Fecha & 1.81 \\
\hline 1 & im & $\mathrm{S}$ & Pis & 0.05 \\
\hline 1 & $\mathrm{im}$ & $\mathrm{S}$ & Pononkis & 0.87 \\
\hline 1 & im & $\mathrm{S}$ & Simelap & 0.65 \\
\hline 2 & $\mathrm{ca} / \mathrm{im}$ & $\mathrm{S} / \mathrm{S}$ & Pike & 5.18 \\
\hline 2 & $\mathrm{ca} / \mathrm{im}$ & $\mathrm{S} / \mathrm{S}$ & Ewal & 0.89 \\
\hline 2 & $\mathrm{ca} / \mathrm{im}$ & $\mathrm{S} / \mathrm{S}$ & Pononlap & 1.55 \\
\hline 2 & $\mathrm{ca} / \mathrm{cy}$ & $\mathrm{S} / \mathrm{S}$ & Foui & 1.80 \\
\hline 2 & $\mathrm{im} / \mathrm{L} s$ & $\mathrm{~S} / \mathrm{L}$ & Manimwek & 0.98 \\
\hline 2 & $\mathrm{bt} / \mathrm{Ls}$ & $\mathrm{M} / \mathrm{L}$ & Aliare & 0.17 \\
\hline 3 & $\mathrm{ca} / \mathrm{cy} / \mathrm{Ls}$ & $\mathrm{S} / \mathrm{S} / \mathrm{L}$ & Pien & 3.89 \\
\hline 3 & cy/im/Ls & $\mathrm{S} / \mathrm{S} / \mathrm{L}$ & Wonalang & 3.14 \\
\hline 3 & $\mathrm{im} / \mathrm{bt} / \mathrm{Ls}$ & $\mathrm{S} / \mathrm{M} / \mathrm{L}$ & Onupuku & 4.66 \\
\hline 3 & $\mathrm{ca} / \mathrm{bt} / \mathrm{Ls}$ & $\mathrm{S} / \mathrm{M} / \mathrm{L}$ & Fatikat & 1.64 \\
\hline 3 & $\mathrm{cy} / \mathrm{bt} / \mathrm{LS}$ & $\mathrm{S} / \mathrm{M} / \mathrm{L}$ & Oninuk & 6.22 \\
\hline 4 & $\mathrm{cy} / \mathrm{im} / \mathrm{bt} / \mathrm{Ls}$ & $\mathrm{S} / \mathrm{S} / \mathrm{M} / \mathrm{L}$ & Lelang & 6.73 \\
\hline 4 & $\mathrm{ca} / \mathrm{im} / \mathrm{bt} / \mathrm{LS}$ & $\mathrm{S} / \mathrm{S} / \mathrm{M} / \mathrm{L}$ & Mariong & 5.96 \\
\hline 4 & $\mathrm{ca} / \mathrm{ja} / \mathrm{bt} / \mathrm{LS}$ & $\mathrm{S} / \mathrm{S} / \mathrm{M} / \mathrm{L}$ & Apisson & 6.45 \\
\hline 5 & $\mathrm{ca} / \mathrm{im} / \mathrm{ja} / \mathrm{bt} / \mathrm{Ls}$ & $\mathrm{S} / \mathrm{S} / \mathrm{S} / \mathrm{M} / \mathrm{L}$ & Satawan & 112.15 \\
\hline 5 & $\mathrm{ca} / \mathrm{im} / \mathrm{ja} / \mathrm{bt} / \mathrm{Ls}$ & $\mathrm{S} / \mathrm{S} / \mathrm{S} / \mathrm{M} / \mathrm{L}$ & $\mathrm{Ta}$ & 155.40 \\
\hline 5 & $\mathrm{ca} / \mathrm{im} / \mathrm{ja} / \mathrm{bt} / \mathrm{Ls}$ & $\mathrm{S} / \mathrm{S} / \mathrm{S} / \mathrm{M} / \mathrm{L}$ & Weito & 7.77 \\
\hline 5 & $\mathrm{ca} / \mathrm{im} / \mathrm{ja} / \mathrm{bt} / \mathrm{Ls}$ & $\mathrm{S} / \mathrm{S} / \mathrm{S} / \mathrm{M} / \mathrm{L}$ & Kuttu & 35.27 \\
\hline 5 & $\mathrm{ca} / \mathrm{im} / \mathrm{ja} / \mathrm{bt} / \mathrm{Ls}$ & $\mathrm{S} / \mathrm{S} / \mathrm{S} / \mathrm{M} / \mathrm{L}$ & Orin & 11.40 \\
\hline 5 & $\mathrm{ca} / \mathrm{im} / \mathrm{ja} / \mathrm{bt} / \mathrm{Ls}$ & $\mathrm{S} / \mathrm{S} / \mathrm{S} / \mathrm{M} / \mathrm{L}$ & Lemasul & 7.37 \\
\hline 5 & $\mathrm{ca} / \mathrm{im} / \mathrm{ja} / \mathrm{bt} / \mathrm{Ls}$ & $\mathrm{S} / \mathrm{S} / \mathrm{S} / \mathrm{M} / \mathrm{L}$ & Alengarik & 17.56 \\
\hline 6 & $\mathrm{ca} / \mathrm{cy} / \mathrm{im} / \mathrm{ja} / \mathrm{bt} / \mathrm{Ls}$ & $\mathrm{S} / \mathrm{S} / \mathrm{S} / \mathrm{S} / \mathrm{M} / \mathrm{L}$ & Moch & 32.58 \\
\hline
\end{tabular}

${ }^{a}$ bt, Emoia boettgeri; ca, E. caeruleocauda; cy, E. cyanura; im, E. impar; ja, E. jakati; Ls, Lamprolepis smaragdina.

${ }^{b} \mathrm{~S}$, small; M, medium; L, large.

Kiester (1983) discussed the zoogeography of a similar (but not identical) assemblage of skinks on Arno Atoll in the Marshall Islands. He reported that the smallest islands had the fewest species and that single-species islands were occupied by the smallest species, a pattern observed also on Satawan Atoll in the study reported here. However, the "single" small species on Arno that Kiester (1983) identified as E. cyanura may have included E. caeruleocauda and E. impar. Subsequent to Kiester's (1983) study, Ineich (1987) and Ineich and Zug (1991) presented morphological evidence for distinguishing between $E$. cyanura and E. impar, which was later supported biochemically (Guillaume and Boissinot 1994, Bruna et al. 1995). Bruna et al. (1996b) recorded E. impar from Arno Atoll, and Brown (1991) recorded E. caeruleocauda there.

Different combinations of Emoia species on Satawan Atoll are most in evidence on the smaller islands. These populations are particularly vulnerable to environmental changes such as those wrought by periodic tropical storms and typhoons. Strong winds and high seas (tidal surges) may result in some islands being completely awash and nearly completely denuded of vegetation, depleting or locally extirpating animal populations. Recolonization or the arrival of addi- 
tional colonists can occur by independent dispersal or assisted by human transport. Trading boats and government supply ships frequently transport cargo from Chuuk main islands to settlements throughout the Mortlocks, and the outer, uninhabited islands are frequently visited by residents of the settlements, thus providing opportunities for the inadvertent translocation of lizards aboard canoes and boats within and among supplies being brought to the islands, and local commodities (palm fronds, pandanus leaves, firewood, coconuts, taro) being brought back to the settlements.

To what extent the different combinations of species recorded among the islands of Satawan Atoll may be distorted by sampling bias is uncertain. The species being surveyed are active and conspicuous during the day, and their presence can usually be detected in a short time. However, the lack of any sightings of Lamprolepis smaragdina during the first 2 days on Manimwek Island, the addition of E. cyanura to the Foui list based on only a single specimen that might easily have been overlooked, and the very likely possibility that L. smaragdina was overlooked on Pike Island given its presence on all nearby islands indicate a need for more extensive surveys to further assess patterns of distribution.

\section{ACKNOWLEDGMENTS}

I thank Aaron Bauer and Hidetoshi Ota for their assistance in identifying images of selected specimens in the Lepidodactylus lugubris complex; Kun Floyd and Joe Saimon for preparing digital images of the study area maps; and Gordon Rodda and George Zug for reviewing the manuscript. I am especially grateful for the assistance and courtesies extended to me by the people of the Mortlock Islands during my visits.

\section{Literature Cited}

Borthwick, M. 1977. Aging and social change on Lukunor Atoll, Micronesia. Ph.D. diss., University of Iowa, Iowa City.

Brown, W. C. 1991. Lizards of the genus Emoia (Scincidae) with observations on their evolution and biogeography. Calif. Acad. Sci. Mem. 15:1-94.

Brown, W. C., and F. Parker. 1977. Lizards of the genus Lepidodactylus (Geckonidae) from the Indo-Australian archipelago and the islands of the Pacific, with descriptions of new species. Proc. Calif. Acad. Sci. 41:253-265.

Bruna, E. M., R. N. Fisher, and T. J. Case. 1995. Cryptic species of Pacific skinks (Emoia): Further support from mitochondrial DNA sequences. Copeia 1995:981983.

- 1996a. Morphological and genetic evolution appear decoupled in Pacific skinks (Squamata: Scincidae: Emoia). Proc. R. Soc. Lond. B Biol. Sci. 263:681-688.

. 1996b. New evidence of habitat segregation between two cryptic species of Pacific skinks (Emoia cyanura, and E. impar). Copeia 1996:998-1005.

Bryan, E. H., Jr. 1971. Guide to place names in the Trust Territory of the Pacific Islands. Pacific Science Information Center, Bishop Museum, Honolulu. Unpaged.

Buden, D. W. 2000. The reptiles of Pohnpei, Federated States of Micronesia. Micronesica 32:155-180.

. 2007. A new species of the genus Lepidodactylus Fitzinger (Squamata: Gekkonidae) from the Mortlock Islands, Chuuk State, Federated States of Micronesia. Pac. Sci. 61:407-414.

Case, T. J., D. T. Bolger, and K. Petren. 1994. Invasions and competitive displacement among house geckos in the tropical Pacific. Ecology 75:464-477.

Crombie, R. I., and G. K. Pregill. 1999. A checklist of the herpetofauna of the Palau Islands (Republic of Belau), Oceania. Herpetol. Monogr. 13:29-80.

Division of Statistics. 2002. FSM national detailed tables, 2000 FSM Census of Population and Housing. Department of Economic Affairs, FSM National Government, Palikir, Pohnpei.

Eldredge, L. G. 2000. Non-indigenous freshwater fishes, amphibians, and crustaceans of the Pacific and Hawaiian Islands. Pages 173-190 in G. Sherley, ed. Invasive species in the Pacific: A technical review and draft 
regional strategy. South Pacific Regional Environment Program (SPREP), Samoa.

Guillaume, C.-P., and S. Boissinot. 1994. Allozyme evidence for specific status of the two French Polynesian skink species in the genus Emoia (Reptilia: Lacertilia). Copeia 1994:1042-1047.

Hunsaker, D. 1966. Notes on the population expansion of the house gecko, Hemidactylus frenatus. Philipp. J. Sci. 95:121122.

Ineich, I. 1987. Description d'une nouvelle espece du genre Emoia (Sauria, Scincidae) en Polynesie francaise. Bull. Mus. Natl. Hist. Nat., Ser. 4. 9:491-494.

Ineich, I., and G. Zug. 1991. Nomenclatural status of Emoia cyanura (Lacertilia, Scincidae) populations in the central Pacific. Copeia 1991:1132-1136.

Kiester, A. R. 1983. Zoogeography of the skinks (Sauria: Scincidae) of Arno Atoll, Marshall Islands. Pages 359-364 in A. G. I. Rhodin and K. Miyata, eds. Advances in herpetology and evolutionary biology, Essays in honor of Ernest E. Williams. Museum of Comparative Zoology, Harvard University, Cambridge, Massachusetts.

Lever, C. 2001. The cane toad: The history and ecology of a successful colonist. Westbury Academic and Scientific, West Yorkshire, United Kingdom.

Marshall, K. M. 1972. The structure of solidarity and alliance on Namoluk Atoll. Ph.D. diss., University of Washington, Seattle.

Marshall, M. 1975. The natural history of Namoluk Atoll, eastern Caroline Islands. Atoll Res. Bull. 189:1-53.

McCoid, M. J. 1996. Putative interactions of geckos in the southern Mariana Islands. Micronesica 28:193-202.
Mueller-Dombois, D., and F. R. Fosberg. 1998. Vegetation of the tropical Pacific islands. Springer-Verlag, New York.

Nason, J. D. 1970. Clan and copra: Modernization on Etal Island, eastern Caroline Islands. Ph.D. diss., University of Washington, Seattle.

- 1975. The strength of the land: Community perception of population on Etal Atoll. Pages 117-159 in V. Carroll, ed. Pacific atoll populations. Association for Social Anthropology in Oceania Monograph No. 3. University of Hawai'i Press, Honolulu.

Petren, K., D. T. Bolger, and T. J. Case. 1993. Mechanisms in the competitive success of an invading sexual gecko over an asexual native. Science (Washington, D.C.) 259:354-358.

Pritchard, P. C. H. 1977. Marine turtles of Micronesia. Chelonia Press, San Francisco.

Schmeltz, J. D. E., and R. Krause. 1881. Ein Beitrag zur Kunde der Südsee-Völker. Die Ethnographhisch-Anthropologische Abtheilung des Museum Godeffroy in Hamburg. L. Friederichsen and Co., Hamburg.

Schwaner, T. D., and I. Ineich. 1998. Emoia cyanura and E. impar (Lacertilia, Scincidae) are partially syntopic in American Samoa. Copeia 1998:247-249.

Tolerton, B., and J. Rauch. n.d. [1949?]. Social organization, land tenure, and subsistence economy of Lukunor, Nomoi Islands. Coordinated Investigation of $\mathrm{Mi}$ cronesian Anthropology (CIMA) Report No. 26. Office of Naval Research and the National Academy of Sciences, Washington, D.C.

Zug, G. R. 1991. The lizards of Fiji: Natural history and systematics. Bishop Mus. Bull. Zool. 2:1-136. 